\title{
PERISTIWA MANGKOK MERAH DI KALIMANTAN BARAT TAHUN 1967
}

\author{
Superman \\ Program Studi Pendidikan Sejarah IKIP-PGRI Pontianak \\ Email: namakusuperman@gmail.com
}

\begin{abstract}
Abstrak
Keterlibatan segelintir masyarakat Cina dalam gerakan politik pada sekitar tahun 1963 di Kalimantan Barat merupakan hal yang menarik untuk diteliti. Mereka terhimpun dalam organisasi PGRS-Paraku yang pada awalnya merupakan gerakan oposisi untuk melancarkan "Ganyang Malaysia". Namun ketika peta politik di Indonesia berubah, PGRS-Paraku kemudian dinyatakan sebagai organisasi terlarang yang harus ditumpas. Hal ini memunculkan konflik yang hebat antara masyarakat Dayak dengan orang-orang Cina Komunis. Masyarakat Cina yang bukan komunis di pedalaman menghadapi dampak yang ditimbulkan. Mereka terpaksa diungsikan ke tempat-tempat aman terutama di Singkawang. Kejadian ini mengakibatkan pengungsi harus memulai kehidupan mereka dari awal kembali karena meninggalkan kehidupan mereka yang sudah cukup memadai di pedalaman sebelumnya.
\end{abstract}

Kata Kunci: Mangkok Merah, Kalimantan Barat, Tahun 1967.

\begin{abstract}
The involvement of a handful of Chinese society in the political movement around 1963 in West Kalimantan is an interesting thing to study. They assembled in PGRSParaku organization which was originally an opposition movement to launch "Ganyang Malaysia". But when the political map in Indonesia changed, PGRS-Paraku later declared a forbidden organization to be suppressed. This gave rise to a great conflict between Dayak and Chinese Communists. The Chinese that not a communist in land face of the impact. They had evacuated to safe places, especially in Singkawang. This incident resulted in the refugees have to start their lives over again due to leave their lives in the inland is sufficient before.

Keywords: Mangkok Merah, West Kalimantan, 1967.
\end{abstract}

\section{PENDAHULUAN}

Tahun 1967 di Kalimantan Barat terjadi pengungsian besar-besaran masyarakat Cina yang tinggal di daerah pedalaman Kalimantan Barat. Peristiwa ini dalam rangka menumpas gerakan Pasukan Gerilya Rakyat Serawak (PGRS) dan Pasukan Rakyat Kalimantan Utara (Paraku) yang anggotanya sebagian besar adalah masyarakat Cina komunis. Upaya penumpasan dilakukan oleh militer serta bantuan dari masyarakat Dayak. Terjadinya perlawanan masyarakat Dayak dipicu oleh peristiwa terbunuhnya beberapa orang Dayak yang diduga pelaku pembunuhan adalah orang Cina komunis. Peristiwa ini menyebabkan masyarakat Cina yang ada di pedalaman diungsikan ke daerah pesisir. Salah satunya adalah ke Singkawang. Keadaan ini menyebabkan mereka harus menyesuaikan dengan lingkungan baru. Banyak diantaranya yang hidup miskin karena kehilangan pekerjaan dan tempat tinggalnya di pedalaman. Pemukiman pengungsipengungsi itu pada umumnya menjadi pemukiman Cina miskin. 
Permasalahan etnis Cina di Indonesia setidaknya hingga masa reformasi sangat menarik untuk dikaji. Upaya etnis Cina untuk diakui sebagai Warga Negara Indonesia (WNI) kala itu bukanlah sesuatu yang mudah. Secara hukum sebagian diantara mereka memang adalah WNI namun kenyataannya mereka harus mengalami banyak peristiwa tragis akibat “kecinaannya”. Timbul persepsi yang menganggap mereka sebagai warga asing meskipun telah lahir dan menetap lama di Indonesia (Leo Suryadinata, 1986:115). Pemisahan etnis Cina dengan warga pribumi oleh pemerintah kolonial Belanda menjadikan mereka sebagai kelompok yang eksklusif. Berbeda dengan kebijakan tersebut, pemerintahan Indonesia yang telah merdeka berusaha untuk menghilangkan unsur eksklusif etnis Cina. Pemerintah menghendaki adanya pembauran. Usaha itu kemudian tidak secara singkat menyelesaikan permasalahan. Kebijakan-kebijakan yang diambil terkesan menyudutkan etnis Cina meskipun telah berstatus WNI.

Etnis Cina terkenal dengan kemapanan ekonominya. Sebagian besar masyarakat Cina di Jawa merupakan pengusaha yang sukses dan kaya. Tidak demikian bagi masyarakat Cina di Singkawang, banyak dari mereka hidup miskin sebagai petani dan buruh. Hal ini menarik untuk dikaji terkait perbedaan antara masyarakat Cina Singkawang dengan masyarakat Cina di daerah lain terutama di Jawa. Persepsi mengenai orang Cina juga sedikit berbeda di daerah ini dibandingkan dengan di daerah lainnya. Orang Cina di Jawa sering mendapatkan persepsi negatif, namun di Kalimantan Barat tanggapan seperti itu tidak begitu besar. Pernah terjadi peristiwa besar yang menewaskan banyak orang Cina di pedalaman Kalimantan Barat, namun hal itu tidak menimbulkan persepsi berlebihan terhadap mereka. Tulisan ini menggambarkan keadaan politik dan sosial-ekonomi masyarakat Cina di Kalimantan Barat pada peristiwa mangkok merah.

\section{METODE PENELITIAN}

Metode penelitian sejarah adalah proses menguji dan menganalisis secara kritis rekaman dan peninggalan masa lampau. Metode sejarah juga merupakan petunjuk pelaksanaan dan petunjuk teknis tentang bahan, kritik, interpretasi dan penyajian sejarah (Kuntowijoyo, 1994:411). Terdapat empat langkah yang merupakan metode penelitian historis kritis menurut Louis Gottschlalk, yaitu heuristik, kritik sumber, interpretasi, serta penulisan atau penyajian (Louis Gottschalk, 1986:6).

Heuristik merupakan serangkaian kegiatan untuk menghimpun jejak-jejak masa lampau yang dikenal dengan 
sumber sejarah. Menurut Garraghan sumber sejarah merupakan bahan-bahan yang dapat digunakan untuk mengumpulkan informasi tentang peristiwa yang terjadi pada masa lampau (Gilbert J. Garraghan, 1957:33$34)$.

Kritik Sumber yaitu kritik dan analisis sumber yang berupa menilai keaslian sumber baik isi maupun bentukbentuknya. Pada tahap ini semua sumber yang telah didapatkan kemudian diperiksa dan diteliti keasliannya dan keakuratannya untuk dapat dipercaya. Tidak semua sumber dapat digunakan dalam menyusun laporan ini. Sumbersumber ini harus diseleksi dan penyeleksiannya harus dapat dipertanggungjawabkan. Kritik sumber ada dua yaitu kritik ekstern dan intern. Kritik ekstern bertujuan untuk mengetahui keotentikan sumber (Gilbert J. Garraghan, 1957: 107). Kritik intern bertujuan untuk mengetahui kebenaran suatu sumber.

Interpretasi adalah yaitu
menetapkan makna yang saling
berhubungan dari fakta-fakta sejarah yang telah diperoleh setelah diterapkan kritik ekstern dan intern. Interpretasi diperlukan untuk mengungkapkan makna dari sumber-sumber sejarah yang telah terkumpul. Tahap ini terbagi kedalam dua langkah yaitu analitis dan sintesis. Analitis berarti menguraikan sedangkan sintesis berarti menyatukan. Dalam tahap interpretasi ini sejarawan dituntut untuk mampu mencari bagianbagian yang hilang dari rangkaianrangkaian peristiwa yang lampau dan mampu menjelaskan kenyataan yang ada di masa lampau.

Historiografi merupakan tahapan terakhir dari kegiatan penelitian sejarah yang menyampaikan sintesa yang diperoleh dalam bentuk karya sejarah (Nugroho Notosusanto, 1971:13). Pada tahap ini aspek kronologis sangatlah penting. Tahap ini memerlukan suatu imajinasi historis yang baik sehingga fakta-fakta sejarah yang sudah benarbenar terpilih, tetapi masih bersifat fragmentasi dapat menjadi suatu sajian yang bersifat utuh, sistematis dan komunikatif.

\section{HASIL DAN PEMBAHASAN}

Terbentuknya PGRS-Paraku

Putusnya hubungan diplomatik antara Indonesia dan Malaysia menyebabkan dampak yang besar bagi masyarakat Kalimantan Barat. Kalimantan Barat dijadikan pangkalan militer utama untuk menghadapi Malaysia. Kota-kota perbatasan seperti Sambas, Bengkayang, Ledo, Sanggauledo dan Putusibau menjadi tempat berkumpulnya pasukan sukarelawan. Salah satu gerakan sukarelawan tersebut adalah gerakan komunis Sarawak. Gerakan ini berawal dari sekolahsekolah, media dan kongsi dagang milik 
orang-orang Cina di Sarawak pada 1950an. Komunisme diajarkan di sekolah Cina. Instansi komunis yang utama berkaitan erat dengan Kuching Chung Hua Schools (KCHS). Dua pemimpin utama KCHS yang kemudian mendirikan Clandestine Communist Organisation (CCO) di Sarawak adalah Weng Min Chyuan dan Bong Kee Chok. Mereka kemudian mendirikan Sarawak Advanced Youth's Association (SAYA) untuk merekrut para siswanya. Mereka juga menjalin hubungan dengan gerakan komunis lain di tingkat regional dan RRC (James Chin, 2004:2-3). Permusuhan Indonesia terhadap Inggris dan Malaysia menguntungkan CCO.

Kedua pemimpin CCO, Bong dan Weng kemudian bertemu dengan anak buahnya yaitu Yap Chung Ho, Wong Hon, Liem Yen Hua dan Yacob dari SAYA. Mereka menetapkan garis perjuangan baru di Kalimantan Barat yaitu bekerjasama dengan Pemerintah Indonesia, Partai Komunis Indonesia dan Negara Kesatuan Kalimantan Utara (NKKU) pimpinan PM A.M Azhari. Indonesia kemudian menjadi sekutu CCO dalam rangka konfrontasi dengan Malaysia. Indonesia menyediakan logistik dan memberikan latihan militer untuk anggota CCO di Kalimantan Barat. Gerakan ini menghimpun kekuatan revolusioner buruh tani dan mempererat hubungan dengan masyarakat Dayak serta membuat basis militer di perbatasan Sarawak-Kalimantan Barat (Komandan Korem 121/Alambhana Wanawwai, 1993:4). Yap Chung Ho mengadakan pertemuan dengan PM Azhari di Sintang nntuk merealisasikan garis perjuangan tersebut. Pada pertemuan tersebut tercapailah kesepakatan meleburkan pasukan TNKU dengan anggota CCO dan SAYA. Inilah gagasan awal lahirnya pembentukan Pasukan Gerilya Rakyat Sarawak dan Pasukan Rakyat Kalimantan Utara (PGRS-Paraku).

Pembentukan Malaysia dinilai oleh kaum komunis dan Soekarno sebagai sebuah rencana neo-kolonialis. Pergolakan politik Indonesia dengan Malaysia telah mengobarkan semangat militer di Kalimantan Barat dibawah pimpinan Brigjen M.S. Supardjo untuk menggalang bantuan dari beberapa organisasi yang tidak setuju dengan pembentukan Federasi Malaysia. Salah satu organisasi tersebut adalah PGRSParaku. Sebenarnya PGRS-Paraku dalam perpolitikannya tidaklah sejalan dengan Indonesia karena pergerakan ini adalah suatu pemberontakan untuk mendirikan wilayah yang merdeka baik dari Indonesia maupun Malaysia.

Indonesia yang pada masa itu membutuhkan dukungan dari banyak kalangan serta kesamaan pandangan dalam hal ideologi menjadikan PGRSParaku dan militer Indonesia dapat berjalan bersama dalam satu kekuatan. 
Posisi PGRS-Paraku yang terhimpit antara Indonesia dan Malaysia juga menyebabkan tidak mungkin untuk melawan dua kekuatan besar tersebut. Jalan keluar bagi mereka adalah bekerjasama dengan salah satu pihak yang dinilai sejalan yaitu Indonesia.

Situasi di Kalimantan Barat pada masa konfrontasi tersebut sangat bergejolak. PGRS-Paraku yang pada umumnya berasal dari sekolah-sekolah berbahasa Cina dilatih militer dan ideologi di pangkalan militer Indonesia di Singkawang. Pelatihan militer dipersiapkan untuk membantu angkatan perang Indonesia menghadapi konfrontasi dengan pihak Malaysia. “... komunis kan dibenci di Malaysia, mereka lari ke Indonesia dan ditampung. Alasan mereka hendak menyerang Malaysia jadi mereka dilatih, ternyata akhirnya senjata makan tuan. Mereka yang dilatih ternyata kumunis-komunis semua" (Wawancara dengan Zainal Arifin pada tanggal 1 Februari 2009). Kekuatan militer Indonesia pada masa itu memang masih sangat kurang terutama mengenai jumlah personil. Kekurangan ini menjadikan pihak Indonesia merekrut semua kalangan yang dapat dirangkul tanpa berpikir dampak yang akan ditimbulan lebih lanjut.

Pasca keluar dari Perserikatan Bangsa-Bangsa (PBB) pada tanggal 7 Januari 1965 Soekarno semakin gencar dalam aksi pengganyangan Malaysia.
Banyak pasukan reguler dan sukarelawan yang dikerahkan ke perbatasan. Rencana untuk rujuk semakin kuat di kalangan pemimpin AD. Brigadir Jenderal Soeharto yang waktu itu menjabat Panglima Kostrad dan Wakil Panglima Komando Ganyang Malaysia terus menggencarkan usaha tersebut. Usaha-usaha yang dilakukan Soeharto diketahui oleh Letnan Jenderal Ahmad Yani (Hidayat Mukmin, 1991:116).

Soeharto kemudian memberikan kuasa kepada Letnan Kolonel (Letkol) Ali Moertopo untuk mengintesifkan dalam usaha rujuk. Ali Moertopo adalah seorang perwira yang memiliki latar belakang intelejen yang lengkap. Ali Moertopo juga dibantu oleh Mayor L. B. Moerdani, Letkol Rachman Ramli dan Letkol Soegeng Djarot. Untuk mencari kontak dengan Kuala Lumpur, Ali Moertopo menggunakan tenaga orangorang sipil yang biasa berdagang atau berwisata ke wilayah Malaysia. Salah satunya adalah Des Alwi. Melalui orangorang itulah Soeharto mendapat kontak pertama dengan Kuala Lumpur. Thailand yang berada di posisi netral menjadi basis diplomasi terselubung tersebut. Selanjutnya pertemuan-pertemuan intensif dengan pihak Malaysia dilakukan pada bulan April, Mei dan Juni 1964 (Hidayat Mukmin, 1991:117-120). Setelah Soekarno lengser dari jabatannya, kondisi untuk rujuk dengan 
pemerintah Malaysia semakin mudah terlaksana.

\section{Penumpasan PGRS-Paraku}

Gagalnya upaya kudeta 30 September 1965 menyebabkan perubahan politik Indonesia. Tahun 1966 perdamaian dengan Malaysia diwujudkan. Brigjen Supardjo yang bertugas di Kalimantan Barat kemudian ditangkap karena terlibat dalam upaya kudeta tersebut. Perubahan politik ini tentu saja menyebabkan Indonesia tidak lagi sejalan dengan politik PGRS-Paraku. Orang-orang yang simpati kepada PGRSParaku masuk ke hutan Kalimantan Barat untuk bergabung dengan mereka di sana. Bulan Juli 1967 PGRS-Paraku menyerang pangkalan udara militer Indonesia di Sanggauledo. Beberapa perwira dan staffnya dibunuh. Mereka juga merebut senjata dan amunisi tentara.

Penumpasan PGRS-Paraku oleh militer mengalami kegagalan. Salah satu penyebab kegagalan tersebut adalah terbatasnya pihak militer setempat baik dalam hal persenjataan maupun dari segi jumlah personil militer yang ada. Hal lain yang menjadi kendala dalam menumpas PGRS-Paraku yaitu adanya bantuan dari penduduk setempat kepada PGRS-Paraku, dalam hal ini adalah pedagang perantara yang ada di pedalaman. Mereka menjadi penyuplai logistik dan kebutuhan para gerilyawan PGRS-Paraku. Bagi para pedagang yang tidak memihak PGRS-Paraku bantuan yang ada terkadang bukan sebagai bantuan sukarela dari mereka, namun lebih cenderung bantuan yang terpaksa mereka lakukan karena rasa takut.

Mengingat keterbatasan militer setempat, pemerintah mendatangkan pasukan dari Jawa untuk membantu proses penumpasan PGRS-Paraku. Pasukan yang didatangkan yaitu pasukan devisi Siliwangi. Pasukan ini tidak menguasai medan operasi, oleh karena itu mereka merekrut beberapa warga sipil sebagai pasukan terdepan. Mereka yang direkrut adalah yang dinilai menguasai medan operasi sebagai penunjuk jalan. Terbentuklah pasukanpasukan tambahan seperti pasukan Kancil dan pasukan Kalajengking. Mereka dipersenjatai lengkap dengan seragam militernya. "Jika ada operasi kami yang maju duluan dan ditemani pasukan Siliwangi... Pasukan hanya pagar betis, kami yang direkrut sebagai perintis... Pasukan yang dibentuk adalah karena pasukan setempat yang mengetahui persis lokasi operasi sehingga dijadikan pemandu untuk operasi militer" (Wawancara dengan Zainal Arifin pada tanggal 1 Februari 2009).

Militer juga meminta dukungan mantan Gubernur Kalimantan Barat Oevang Oeray supaya orang Dayak dapat membantu tentara untuk menumpas para pemberontak. Oevang Oeray 
merupakan gubernur sekaligus tokoh yang sangat disegani orang Dayak di Kalimantan Barat. Masyarakat Dayak dihimbau untuk ikut berpartisipasi bersama tentara untuk menumpas PGRSParaku. Militer melakukan propaganda di kalangan tokoh Dayak dengan menyebarkan beberapa isu bahwa orang-orang komunis tidak menyukai sistem Dayak. Para Panglima direkrut dengan dalih bahwa PGRS-Paraku akan menguasai Kalimantan Barat.

Pangdam XII Tanjungpura juga mendatangi beberapa pemuka suku Dayak. Para pemuka Dayak diprovokasi dan ditanamkan pengertian bahwa PGRS-Paraku adalah komunis yang tidak beragama dan orang Dayak tidak bisa hidup bersama-sama komunis. Dijelaskan pula bahwa PGRS-Paraku adalah Cina Sarawak yang ingin memecah belah keamanan wilayah RI. Tentu saja dampaknya adalah terganggunya keamanan orang Dayak. Terjadi pembunuhan orang dayak yang tidak diketahui pembunuhnya di daerah Ledo, Seluas, Pahauman, Bengkayang dan hampir di seluruh wilayah yang terdapat kumunitas Cina dan Dayak. Situasi ini dimanfaatkan oleh pihak militer untuk menjadikan PGRS-Paraku sebagai tersangka pelaku pembunuhan. Ini merupakan provokasi dari tentara agar mendapat dukungan yang penuh dari masyarakat Dayak. Provokasi ini kurang berhasil. Tidak ada tanggapan yang berarti dari masyarakat Dayak.

Untuk mengalahkan perang gerilya yang dilakukan PGRS-Paraku pada prinsipnya harus dipisahkan dengan masyarakat. Orang Cina dan Dayak pedalaman cukup memberikan kontribusi yang berarti bagi PGRSParaku. Pasukan PGRS-Paraku mendapatkan suplai makanan dari penduduk di pedalaman khususnya dari pedagang Cina yang bekerja sebagai pedagang perantara di sana. Berkaitan dengan adanya kontribusi ini militer berusaha untuk memutus kontribusi pedagang Cina dengan memindahkan seluruh warga Cina dari pedalaman ke pesisir.

Para pemimpin Dayak menemui Oevang Oeray untuk membicarakan pengusiran orang Cina dari pedalaman. Pertemuan diadakan di Pontianak. Hasil pertemuan diikuti dengan pengumuman di radio agar orang Dayak melakukan pengusiran. Oevang menulis surat dan membacakannya sendiri di radio Radio Republik Indonesia (RRI) Pontianak yang berisi orang Cina harus meninggalkan wilayahnya dan pindah ke kota kecamatan terdekat. Pengumuman diikuti surat undangan menghadiri pertemuan pada 11 Oktober 1967. Seluruh kepala kampung di Kewedanan Bengkayang, diminta datang ke Samalantan. Pertemuan dihadiri Oevang dan dijaga ketat tentara. Oevang 
memerintahkan kepada seluruh kepala kampung, bersiap-siap menunggu hari yang disebutnya Gerakan Demonstrasi.

Militer juga menyebarkan kabar angin bahwa orang-orang Komunis akan mengadakan pemberontakan di Kalimantan Barat pada bulan Oktober 1967. Orang-orang Dayak yang merasa bertanggung jawab atas kondisi daerahnya mulai bergerak dan bergabung dengan pihak militer. Puncaknya adalah ketika tersebar isu tewasnya Camat Ledo.

"Saya pulang libur bersama adik saya dijemput oleh bapak saya. Sampai di Bengkayang kami ditawari untuk ikut mobil tentara kujang yang sedang melakukan pertukaran dengan RPKAD. Kira-kira 4 kilometer dari Ledo kami dicegat oleh PGRSParaku. 7 tentara kujang gugur. Saya sendiri kena peluru di kaki. Adik saya terkena tembakan dikeningnya. Saat itu bapak saya sebagai Camat Ledo. Orang dayak marah, mereka tidak terima dikira bapak saya meninggal. Lalu terjadilah mangkok merah" (Wawancara dengan I. Libertus Ahie pada tanggal 15 Januari 2009).

Akhirnya diketahui peristiwa terbunuhnya Camat Ledo oleh PGRSParaku tidak benar, namun terjadinya peristiwa pencegatan tersebut dan peristiwa-peristiwa yang meresahkan lainnya sudah terlanjur mengakibatkan orang Dayak tidak hanya berdiam diri. Mereka kemudian menyerukan untuk mengumpulkan kekuatan melalui mangkok merah.

\section{Peristiwa Mangkok Merah Tahun 1967}

Mangkok merah adalah satu dari sekian banyak cerita tentang kekuatan supranatural suku Dayak. Mangkok merah dapat diartikan ganda sebagai kata benda atau sebagai sebuah ritual dan kegiatan. Sebagai sebuah ritual, mangkok merah erat kaitannya dengan kegiatan perang. Mangkok merah merupakan sebuah alat konsolidasi dan mobilisasi pasukan lintas sub-suku yang efektif dan efesien. Mangkok merah juga merupakan simbol dimulainya peperangan.

Ada dua makna dari mangkok merah, jika didalam mangkok bukan darah itu artinya pemberitahuan siapsiap ada bahaya. Kalau mangkok di dalamnya darah berarti pemberitahuan siap perang. Setiap kampung yang dilewati tidak boleh berhenti, terus semua kampung dan semua laki-laki yang ada di kampung itu harus siap perang untuk membantu saudarasaudara mereka yang disakiti atau dibunuh (Wawancara dengan I. Libertus Ahie pada tanggal 15 Januari 2009).

Harus ada alasan kuat yang menyangkut harga diri atau susuatu yang mengancam eksistensi suku Dayak barulah mangkok merah boleh diedarkan. Mangkok merah diedarkan dari kampung ke kampung sebagai permintaan bantuan dalam peperangan. Kampung yang dikunjungi mangkok merah wajib melaksanakannya. Ritual mangkok merah dimulai ketika kepala 
suku atau kepala adat suatu sub-suku tertentu meminta bantuan sub-suku lain untuk membantunya dalam peperangan (Edi Petebang, 1999:94).

Kekerasan pecah pertama kali pada tanggal 14 Oktober 1967 di Taum, selatan Sanggauledo. Penyerangan yang dilakukan orang-orang Dayak ini dinamakan demonstrasi. Istilah halus ini membenarkan keterlibatan militer di dalamnya. Akhir bulan Oktober 1967, orang-orang Dayak menyerang rumah orang Cina di daerah Anjungan, Mandor dan Menjalin (Mary Somers Heidhues, 2008:271). Berbeda dengan di wilayah utara, di sini orang-orang Cina melakukan perlawanan.

Awalnya penyerangan dilakukan dengan sopan dan tertib. Kelompok pertama yang datang bertindak disiplin. Kelompok ini dibentuk dari orang-orang Dayak Sambas dan Mempawah yang memiliki hubungan baik dengan orang Cina. Para saksi mata mengatakan bahwa mereka bertindak disiplin. Mereka mengambil barang-barang dari toko kemudian dihancurkan, tetapi tidak dijarah. Orang Cina yang tidak melawan dibiarkan mengungsi ke wilayah pantai, walaupun barang-barangnya tidak selamat (Mary Somers Heidhues, 2008:271-272).

Suasana berubah ketika beberapa pemuda Cina melakukan serangan balik. Kekerasan pun semakin meningkat, inilah saat di mana orang- orang Dayak mulai menggunakan senjata api. Kekerasan memuncak ketika Dayak Menyuke turut serta dalam gelombang demonstrasi tersebut. Tanggal 14 November 1967 kelompok-kelompok Dayak dari pelosok pedalaman datang. Mereka bertindak diluar kontrol, membunuh bahkan dikabarkan juga memakan bagian tubuh korban-korban mereka (Herman Josef Van Hulten, 1992:284)

Ribuan orang Dayak dari berbagai sub-suku berkumpul di Menjalin dipimpin oleh Dayak Menyuke. Mereka menuju Toho dan ke Anjungan untuk menyerang pemukiman-pemukiman Cina. Mereka juga berencana hendak menuju Sungai Pinyuh, sebuah daerah pantai di mana secara tradisional bukan wilayah mereka. Sungai Pinyuh adalah wilayah strategis penghubung antara Pontianak dengan kota-kota di utara seperti Singkawang dan Sambas, di mana banyak bermukim orang-orang Cina. Hal ini tentu mencemaskan pemerintah, oleh karena itu militer segera mencegah masuknya kelompok tersebut agar tidak memasuki Sungai Pinyuh (Mary Somers Heidhues, 2008:272).

Kerusuhan juga terjadi di Capkala dan daerah-daerah lainnya, tetapi penduduk Cina telah mengungsi terlebih dahulu sebelum keadaan menjadi lebih buruk. Mereka memiliki kebun karet dan ladang-ladang, akan 
tetapi mereka tidak berusaha untuk mempertahankannya. Pada awalnya kaum laki-laki Cina berniat untuk tetap tinggal, namun hal tersebut tidak terjadi. Kaum perempuan dan anak-anak melarikan diri atau bersembunyi dari penyerangan di berbagai tempat (Herman Josef Van Hulten, 1992:290292).

Peristiwa tersebut terjadi dari daerah-daerah lain.

“Tanggal 27 oktober 1967 panglima berhias pakaian dayak badannya penuh darah datang masuk ke kota menebang pohonpohon pisang dan membunuh anjing langsung ke kantor lurah membawa surat dengan tanda tentara Kujang Divisi Siliwangi. Saya diminta kepala desa menterjemahkan bahasa yang tidak dimengerti. Mangkok merah diberikan kepada kepala desa beserta surat. Ditanya tentang orang yang berkaitan dengan komunis. Mereka pergi dari kantor lurah, saya pulang dan saya dengar ada orang yang dibawa. Anak istri saya titipkan dikampung tempat rekan kerja saya" (Wawancara dengan Andrias Japri Pada Tanggal 8 Agustus 2009).

Kekerasan mencapai puncaknya pada bulan November, para penyerang dengan senjata berburu mulai membunuhi orang-orang Cina dan membakar harta bendanya. Toko-toko Cina dibakari dan mayat-mayat orang Cina dibariskan di jalan Sebadau dan Mandor. Pada toko-toko Cina Menjalin dan Anjungan hampir tidak ada barang yang tersisa namun masih berdiri. Padi di sawah-sawah milik orang Cina dipanen oleh orang Dayak yang sawahnya sendiri belum siap panen (Herman Josef Van Hulten, 1992:292293).

Militer berusaha untuk mengamankan kota-kota utama seperti Singkawang dan Mempawah agar tidak dimasuki kelompok-kelompok penyerang. Wilayah-wilayah tempat terjadinya kekerasan membentang dari Bengkayang di utara ke selatan sampai di Anjungan dan ke timur sampai di Sanggau. Kira-kira luasnya mencapai 150 $\mathrm{km}$ persegi. Kerusuhan yang paling parah adalah di segitiga Anjungan, Mandor dan Menjalin (Mary Somers Heidhues, 2008:273). Hal itu menjadi sangat aneh ketika melihat wilayahwilayah tersebut bukanlah PGRS/Paraku yang menjadi latar belakang konflik. PGRS/Paraku adalah pasukan yang beroperasi pada wilayah perbatasan di utara. Sementara wilayah-wilayah yang mengalami kekerasan paling parah malah berada jauh di selatan wilayah operasi PGRS/Paraku apalagi dapat dikatakan bahwa hubungan Tionghoa dan Dayak di daerah-daerah tersebut sebelumnya baik-baik saja.

\section{Masyarakat Cina Pasca Peristiwa Mangkok Merah}

Peristiwa mangkok Merah setidaknya secara langsung diperkirakan menewaskan 2.000 sampai 3.000 orang meninggal dunia, namun dampak secara tidak langsung diperkirakan lebih banyak 
lagi. Minggu-minggu pertama pengungsian diperkirakan antara 50.000 sampai 80.000 yang bergerak meninggalkan pedalaman menuju pesisir Kalimantan Barat, 4.000 orang diantaranya meninggal di daerah pengungsian.

"Mereka makan tidak cukup. Mereka memasak dengan kaleng-kaleng yang sudah berkarat akibatnya mereka sakit dan meninggal. Di jalan kuala kondisi yang paling memprihatinkan. Setiap hari saya berkunjung kesitu ada yang meninggal" (Wawancara dengan Andrias Japri Pada Tanggal 8 Agustus 2009). "Anak-anak banyak yang meninggal karena kekuragan makanan. Anak-anak yang meninggal digantung di kayu untuk menunggu mobil jemput. Saudara saya ada yang meninggal yaitu kakak dan adik saya" (Wawancara dengan Bong Kie Cau pada tanggal 6 Agustus 2009). Mereka yang mengungsi terserang penyakit dan menderita kelaparan serta kekurangan gizi. Kondisi semakin membaik ketika bantuan berdatangan dari berbagai kalangan yang diantaranya adalah Palang merah Internasional dari PBB, kelompok perlindungan gereja dan perkumpulan marga Cina di Pontianak dan daerah sekitarnya.

Pasca peristiwa Mangkok merah kekurangan pangan dan inflasi terus meningkat. Daerah bekas hunian Cina yang terdapat toko, rumah dan ladang orang-orang Cina pedalaman diambil alih oleh orang-orang Dayak. Orang Dayak menggantikan posisi mereka sebagai pedagang di pedalaman. Orang Dayak yang tidak memiliki jaringan bisnis seperti orang Cina menyebabkan perekonomian yang sebelumnya maju di kalangan Cina di tangan orang-orang Dayak perekonomian tidak sepesat sebelumnya.

Kalimantan Barat secara geografis sangat luas, namun lahan untuk para pengungsi bercocok tanam tidak ada. Sebagian dari masyarakat Cina dari pengungsian kemudian berpindah ke kota Pontianak. Sebagian lainnya memilih untuk diam di pinggir kota Singkawang dan kota-kota lainnya. Untuk menciptakan lapangan pekerjaan bagi para pengungsi, pemerintah Kota Singkawang kemudian membuka beberapa industri perkayuan. Banyak di antara para pengungsi kemudian yang terserap di Industri tersebut. Hal ini sedikit meringankan beban hidup para pengungsi yang telah kehilangan segala harta benda mereka.

Sejak tahun 1967, kebijakan pemerintah memindahkan orang Cina ke daerah pesisir telah menggeser mereka dari perkampungan dan mendorong keterpusatan di kota dekat pesisir. Hal ini juga menyebabkan kemiskinan yang melanda sebagian besar masyarakat Cina di Singkawang pada masa awal Orde Baru. Mereka tidak memiliki harta 
benda di daerah yang baru. Tidak jarang anak perempuan dari Cina miskin melakukan perkawinan dengan laki-laki Taiwan yang kaya kemudian menetap di Taiwan. Hal ini tenntu saja untuk peningkatan ekonomi mereka (Agus Sikwan dan Maria Rosarie Harni Tiastuti, 2004:49). Orang tua yang merelakan anak mereka menikah dengan orang Taiwan tersebut berharap mendapatkan kiriman uang dari anaknya di luar negeri.

Peristiwa tahun 1967 di pedalaman Kalimantan Barat merupakan faktor terbesar penyebab terjadinya kemiskinan orang Cina di Singkawang. Mereka yang miskin sebagian besar adalah masyarakat Cina yang menjadi korban peristiwa tersebut. Para pengungsi yang ada di Singkawang memulai kehidupan dari awal tanpa perbekalan modal usaha. Mereka menggantungkan hidup seadanya dari bertani dan menjadi nelayan. Boleh dikatakan kondisi sebagian dari mereka yang mengungsi masih mengalami kesulitan ekonomi bahkan hingga sekarang. Keadaan ini tentu saja menjadi faktor pembeda antara masyarakat Cina di Singkawang dengan di daerah lain ketika kita mengkaji beberapa kebijakan ekonomi yang diterapkan oleh pemerintahan Soeharto yang umumnya memacu perekonomian para pengusaha Cina.
Umumnya setelah tahun 1967 muncul kecenderungan bertambah banyaknya orang Cina yang kemudian berdagang. Kecenderungan ini muncul akibat bertambah banyaknya pengungsi yang datang ke Singkawang. Orang Cina yang memiliki modal membuka usaha perdagangan sementara yang tidak memiliki modal bekerja sebagai buruh dan bertani. Periode ini adalah masamasa sulit bagi orang Cina di Singkawang. Terbatasnya lapangan pekerjaan sementara pencari kerja yang banyak menyebabkan banyak diantara mereka yang menganggur. Periode 1970an di Singkawang sektor pertanian dan perkebunan mulai banyak ditinggalkan sementara sektor perdagangan mulai diminati.

\section{PENUTUP}

\section{Kesimpulan}

Memasuki tahun 1963 ada suatu kecenderungan masyarakat Cina untuk ikut serta berperan dalam dunia perpolitikan. Mereka berperan dalam berbagai organisasi politik. Konfrontasi dengan Malaysia menyebabkan Kalimantan yang berbatasan langsung dengan Malaysia dijadikan sebagai pangkalan militer untuk menghadapi segala kemungkinan perang antara Indonesia-Malaysia. Indonesia menempatkan para sukarelawan di perbatasan. Indonesia juga menjalin kerja sama dengan PGRS-Paraku yang 
pada masa itu terhimpit dua kekuatan besar yaitu Indonesia dan Malaysia.

PGRS-Paraku memilih Indonesia sebagai sekutu memusuhi Malaysia karena Indonesia yang pada masa itu sejalan dengan pergerakan tersebut menerapkan paham komunis. Sebenarnya PGRS-Paraku dalam cita-cita politiknya sangat bertentangan dengan pemerintah Indonesia. Namun kondisi Indonesia yang membutuhkan banyak dukungan terkesan memaklumi sementara pergerakan yang lebih bersifat makar tersebut.

Konsolidasi kemudian dijalin pihak Indonesia dengan Malaysia dibawah kepemimpinan baru yaitu Rezim Soeharto. Segala bentuk komunisme dilarang di Indonesia di bawah kepemimpinan rezim baru ini. Hal ini berdampak pada penumpasan PGRS-Paraku yang pada awalnya bersama-sama dengan Indonesia dalam melakukan konfrontasi terhadap Malaysia.

Pemerintah mengirimkan militer ke Kalimantan Barat untuk menumpas PGRS-Paraku yang beroprasi di pedalaman Kalimantan Barat. Umumnya mereka yang tergabung dalam keanggotaan PGRS-Paraku mayoritas adalah masyarakat Cina Sarawak yang berpaham komunis. Mereka direkrut dari sekolah-sekolah berbahasa pengantar Cina. PGRS-Paraku dalam melakukan kegiatannya disuplai oleh pedagang perantara yang ada di pedalaman Kalimantan Barat. Pihak militer mengalami kendala dalam menumpas pergerakan tersebut.

Militer kemudian melakukan siasat untuk mengasingkan PGRS-Paraku dengan mengungsikan masyarakat Cina dari pedalaman ke pesisir agar pergerakan PGRS-Paraku semakin terhimpit. Militer juga melakukan provokasi kepada orang-orang Dayak untuk bekerja sama dalam menumpas PGRS-Paraku. Siasat demi siasat dilakukan agar orang dayak mau bergabung bersama militer hingga akhirnya terjadi pembunuhan beberapa orang Dayak yang diduga pelakunya adalah PGRS-Paraku.

Kondisi ini tentunya menyulut kemarahan orang-orang Dayak sehingga akhirnya mereka bergabung dengan militer dalam penumpasan PGRS-Paraku. Terjadi sebuah perperangan yang disebut peristiwa Mangkok Merah. Peristiwa ini mengakibatkan paling tidak 3.000 korban tewas terbunuh di pedalaman dan sekitar 4.000 korban tewas di pengungsian karena buruknya gizi. Para pengungsi hidup di penampungan dalam waktu yang cukup lama. Mereka harus memulai kehidupan mereka dariawal karena kehilangan tanah rumah dan penghidupan mereka di pedalaman.

Peristiwa Mangkok Merah menyebabkan kondisi sosial-ekonomi 
yang cukup buruk di masa awal Orde Baru di Kalimantan Barat. Banyak diantara pengungsi yang memilih untuk tinggal di kota Pontianak dan sebagian lainnya hidup di pinggiran kota Singkawang. Terciptalah lingkungan Cina miskin di Singkawang. Umumnya mereka yang mengalami peristiwa Mangkok Merah, perekonomiannya sulit untuk bangkit kembali. Mereka kebanyakan menjadi petani-petani kecil di pinggiran kota Singkawang dan banyak juga diantaranya yang bekerja sebagai nelayan dan buruh kasar.

\section{DAFTAR PUSTAKA}

Agus Sikwan, Maria Rosarie Harni Tiastuti. (2008). Tragedi Perdagangan Amoi Singkawang. Yogyakarta: Universitas Gadjah Mada.

Cator, W. J. (1936). The Economic Position of the Chinese in the Netherlands indies. Oxford: Basil Blackwell \& Mott ltd.

Chin, James. (2004). The Rise and Fall of Communism in Sarawak 19401990. Melbourne: Monash Asia Institute. 2004.

Edi Petebang. (1999). Dayak Sakti: Pengayauan Tariyu, mangkok Merah, Konflik Etnis di Kalbar 1996/1997. Pontianak: Insitut Dayakologi.

Garraghan, Gilbert J. (1957). A Guide to Historical Method. New York: Fordham University.

Gottschalk, Louis. (1986). Understanding History: A Prime of Historical Method, a.b. Nugroho Notosusanto, Mengerti Sejarah. Jakarta: UI Press.

Hidayat Mukmin. (1991). TNI Dalam politik Luar Negeri: Studi kasus Penyelesaian Konfrontasi
Indonesia-Malaysia.

Jakarta:

Pustaka Sinar Harapan.

I. Wibowo. (1999). Retrospeksi dan Rekontekstualisasi Masalah Cina. Jakarta: PT. Gramedia Pustaka Utama.

Komandan Korem 121/Alambhana Wanawwai. (1993). Peranan ABRI dan Masyarakat dalam Penumpasan Gerakan PGRS/Paraku di Kalimantan Barat. Pontianak: Korem 121/Alambahana Wanawwai.

Kuntowijoyo. (1994). Metodologi Sejarah. Yogyakarta: Tiara Wacana.

Leo Suryadinata. (1986). Pribumi Indonesians, the Chinese Minority and China: A Study of Preceptions and Politicies, a.b. Wilandari Supardan, Dilema Minoritas Tionghoa. Jakarta: Grafity Pers.

Nugroho Notosusanto. (1971). NormaNorma Dasar Pemikiran dan Penulisan Sejarah. Jakarta: Dephankam.

Somers Heidhues, Mary. (2008). Golddiggers, Farmers, and Traders in the Chinese Districts of West Kalimantan, Indonesia. a.b. Asep Salmin,Sukma Mihardja dkk. Penambang Emas, Petani, dan Pedagang di Distrik Tionghoa Kalimantan Barat. Jakarta: Yayasan Nabil.

Van Hulten, Herman Josef. Catatan Seorang Misionaris: Hidupku di Antara Suku Daya. Jakarta: Gramedia Widiasarana Indonesia.

\section{Sumber Lisan (Wawancara)}

Wawancara dengan Zainal Arifin pada tanggal 1 Februari 2009

Wawancara dengan I. Libertus Ahie pada tanggal 15 Januari 2009

Wawancara dengan Bong Kie Cau pada tanggal 6 Agustus 2009

Wawancara dengan Andrias Japri Pada Tanggal 8 Agustus 2009 